UNIO - EU Law Journal. Vol. 3, No. 2, July 2017, pp 89-103.

®2017 Centre of Studies in European Union Law

School of Law - University of Minho

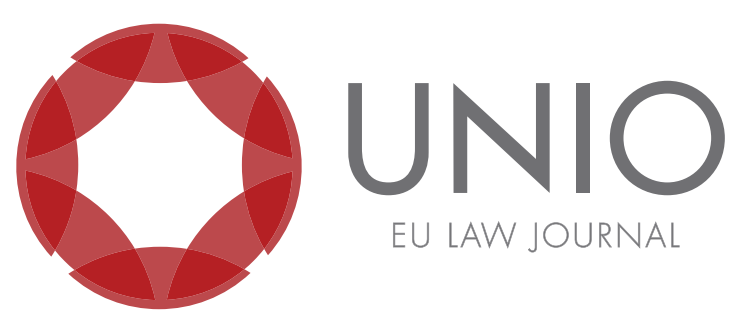

\title{
Control of the Administration and competition policy
}

\author{
María Pilar Canedo Arrillaga*
}

ABSTRACT: This article seeks to analyse what is the purpose competition law serves in today's society and reflect on how significant public authorities are in its application, both with an active and passive role. It analyses the main channels open to competition authorities, in order to bring to light possible breaches of competition principles committed by administrations and which are the most useful tools for stopping them. The paper considers that the role of public administrations in markets as regulators, providers of aid, economic operators or facilitators of contracting between companies is highly significant and may have a major influence on those markets. The proper exercise of these functions results in bighly positive values for consumers and in an increase of the common good. Improper actions of the administration can be seriously harmful to the general interest. It concludes that ensuring the proper operation of the markets is essential if periods of economic recession are to be overcome. As such, public administrations must fulfil their mandate of guaranteeing the general good, shying away from sectoral interests that could bring increased short-term benefits but result in dysfunctions and harm for the common good and for consumers.

KEYWORDS: competition law - public administration - regulation - policy control - economic impact.

\footnotetext{
* Professor of Private International Law of the University of Deusto. Member of the Board of the Spanish Commission for Markets and Competion.
} 


\section{Introduction}

This article seeks to analyse what is the purpose competition law serves in today's society and reflect on how significant public authorities are in its application, both with an active and passive role.

Under the European model of the enforcement of competition law, administration (not jurisdiction) has the role of applying, in the first instance, regulations to defend competition. This raises the question on how the administration that applies the rules and acts largely as a regulator itself, can be also subject to competition rules. Also, it is necessary to analyze the main channels open to competition authorities, in order to bring to light possible breaches of competition principles committed by administrations and which are the most useful tools for stopping them. ${ }^{1}$

\section{A global perspective of competition law}

Competition law is one of the most effective responses the State and public authorities in general have to prevent abusive practices from being committed by the strongest market operators in an attempt to maximise their profits, to the detriment of weaker operators and, ultimately, consumers. ${ }^{2}$

Competition policies also seek to enforce market rules on public authorities themselves. ${ }^{3}$ The aim is to stablish limits to their ability to regulate sectors so as to guarantee freedom of business. The administrations are not subject to the same rules applied to private operators, but the same principles need to be respected, so that opportunities for all are protected, and that the provision of public services is offered in the best possible conditions so that the public interest is safeguarded. ${ }^{4}$

In this area, as in many others, the globalisation of the economy has made the protection of domestic markets via national legislation in each country (which is absolutely essential in any economy that seeks reasonable levels of competitiveness) fundamental but insufficient in itself for achieving the desired goals. ${ }^{5}$

Various supra-national bodies have, therefore, striven to introduce closer harmony in the principles that govern competition rules and to foster extra-territorial enforcement. The aim is to effectively apply shared principles and combat the practices of large-scale operators which are capable of extending their operations

\footnotetext{
1 Ricardo Alonso Soto, "Recomendaciones de la CNC a las administraciones pública", Boletín Informativo Gomez-Acebo \& Pombo Abogados 4 (2008) 16- 21; Ricardo Alonso Soto, "Recomendaciones de la CNC a las administraciones pública”, Boletin Informativo Gomez-Acebo \& Pombo Abogados 5 (2009) $18-27$.

${ }^{2}$ Oles Andriychuk, "Can we protect competition without protecting consumers?", Competition Law Review, v. 6, issue 1 (2009) 77 - 88; CSERES, Kj, “What has competition done for consumers in Liberalised Markets?", Competition Law Review, v. 4, issue 2 (2008) 77 - 121; Maria Ioannidou, “Enhancing the Consumers' Role in EU Private Competition Law Enforcement: A normative and practical approach", Competition Law Review, v. 8, issue 1 (2011) 59 - 85.

${ }^{3}$ Tomás Arranz and Luis Moscoso del Prado, "Desarrollo reciente de la aplicación de las normas de defensa de la competencia a las Administraciones Públicas”, Revista Actualidad Jurídica URIA 32 (2012): 85-89.

${ }^{4}$ Maria Pilar Canedo Arrillaga, "El derecho de la competencia ante la globalización y la crisis" in Retos del Derecho ante una economia sin fronteras (Bilbao: Deusto, 2012): 231-239.

5 Qianlan Wu, Competition laws, globalization and legal pluralism: China's experience (Oxford: Hart Publishing, 2013); David J. Gerber; "Globalization and Legal Knowledge: Implications for Comparative Law", Tul. L. Review 75 (2001); David J. Gerber, "Europe and the globalization of Antitrust Law”, Conn. J. Int'l L. 14 (1999).
} 
beyind national borders and setting up wherever is most favourable to their own particular interests. ${ }^{6}$

The efforts made by the European Union in the field of the supra-national protection of competition law certainly stand out above the rest in terms of their generalisation across the Member States, of their effects on the markets in those States, and of their extra-territorial consequences. ${ }^{7}$ Ever since the EU was founded, its Treaties have included rules inspired, partially, by German regulations and partially, by US regulations (or rather set up in response to the latter). The goal of a Single Market within the EU cannot be achieved without effective competition. The idea that underlies the Single Market is to make the EU a single territory in which people, capital, goods and services interact freely, thus fostering competition and trade and improving efficacy. ${ }^{8}$

There is firm evidence that a wider choice of goods and services increases quality and reduces prices, which leads to greater prosperity for the market and for consumers. ${ }^{9}$ For the advantages of the Single Market to filter down to all individuals and small businesses, suppliers and service providers must be able to compete fairly for every contract. ${ }^{10}$ Only effective competition can bring about low prices, higher quality and more variety on offer to consumers. The governments of the European Union have delegated broad powers to the European Commission for the application of anti-trust legislation to enforce its rules on competition, with the express purpose of directly benefiting consumers. ${ }^{11}$

Along with its day-to-day remit of protecting markets, in regard to action by businesses, the Commission also supervises competition in public services (including such important services as telecommunications, electricity and gas), in which the EU has done away with the old state-run monopolies. ${ }^{12}$ It also seeks to ensure that public procurement operations take place in line with the rules of the game of any effective market. ${ }^{13}$ Its objective in this is to strike a reasonable balance, to ensure that the State (directly or through publicly run companies) cannot use its privileged situation in the market to harm new or weaker operators, and, at the same time, to ensure that basic

\footnotetext{
${ }^{6}$ Chris Noonan, "Globalisation, international enforcement and extraterritoriality", Competition Law Review, v. 5, issue 2 (2009) 147 - 151.

${ }^{7}$ Fraser Cameron, "The European Union as a model for regional integration”, Council on Foreign Relations, Working Paper (2010).

${ }^{8}$ Alina Kaczorowska, "The objectives of the competition policy of the CARICOM Single Market and Economy (CSME) and their importance to the development of a coherent and comprehensive body of substantive competition rules in the CSME", Competition Law Review, v. 8, issue 2, (2012): 185 - 207; Matteo Negrinotti, "The single market imperative and consumer welfare: irreconcilable goals? Exploring the tensions amongst the objectives of European competition law through the lens of parallel trade in pharmaceuticals", in The goals of competition law, ed., Daniel Zimmer (UK: Edward Elgar Publishing, 2012), 295-337.

${ }^{9}$ M. J. Vázquez Pena, El derecho de la libre competencia como instrumento de progreso económico a favor de las empresas y de los consumidores (Valencia: Tirant Lo Blanch, 2013).

${ }^{10}$ David Ortega Pesciña, "Defensa de la competencia y protección de los consumidores - Una visión consumerista practica", Boletin Latinoamericano de Competencia 21 (2006): 158-165.

${ }^{11}$ Jose Antonio Rodriguez Miguez, "Descentralización y eficiencia en la protección de los consumidores y la competencia: El caso Español”, Revista de Derecho de la Competencia, v. 10, issue 10 (2014): 207-233.

12 Tribunal de Defensa de la Competencia, Informe sobre remedios políticos que pueden favorecer la competencia en los servicios y atajar el daño causado por los monopolios (1993).

${ }^{13}$ Natalia Fabra, "El funcionamiento del mercado eléctrico español bajo la ley del sector eléctrico" in Energía: del monopolio al mercado, ed. José Luis García Delgado (Cizur Menor: Thomson-Civitas, 2006): $247-275$.
} 
services are provided which are affordable to lower-income customers and disabled persons, and to those who live in remote or peripheral regions. ${ }^{14}$

The Commission also monitors the potential effects of state aid on markets, as they may distort competition between companies and affect trade between EU countries. ${ }^{15}$ If some firms receive government support, this could be seen as giving them an unjustified advantage over their competitors. This is why EU rules, in general, prohibit state aid, though some exemptions are permitted, e.g. for less favoured regions, small businesses and certain frameworks that foster research and development, environmental protection, training, employment and culture.

\section{Administrations and competition law}

Traditionally, competition law was intended to protect markets against private operators which, for whatever reason, seek to alter the rules of the game for their own benefit, and therefore, in detriment of the interests of their competitors, consumers and, ultimately, of society as a whole. Conventionally, competition policies have been aimed directly at businesses (especially at the most economically powerful ones) which see the absolute freedom of the traditional laissez-faire system as an ideal medium for altering markets for their own benefit.

However, questions have recently begun to be asked regarding the extent to which the actions of public-sector actors can alter free competition, by -more or less consciously- favouring certain operators for various reasons, to detriment of the general interest that their ations should be seeking to protect. ${ }^{16}$

The leading international organisations in the field, such as the OECD, UNCTAD and indeed the EU itself, have begun to implement a number of schemes intended to show that inappropriate actions by public administrations can cause breaches of competition laws, with consequences just as serious as those caused by businesses, and may, indeed, have more negative effects than those caused by the private sector. ${ }^{17}$

In terms of both the task of regulation in itself and of the leading role of administrations in public procurement, dysfunctions caused by public administrations can be harmful to the general interest, and must, therefore, be taken into account and avoided insofar as is possible, as a way of achieving a fairer, more efficient contribution to the welfare state. ${ }^{18}$

\footnotetext{
${ }^{14}$ Gerard Pérez Olmo et al, "El derecho de la competencia y las instituciones (o viaje de un casi monopolio a un mundo competitivo)" in La Ley 15/2007, de Defensa de la Competencia, capitulo I Aspectos institucionales, ed. Antonio Creus Carreras (Madrid: La Ley, 2008), 25-42.

${ }^{15}$ Conor Quigley, European state aid law and policy (Oxford: Hart Publishing,2015); F. J. Säcker and F. Montag, European state aid law: a commentary (Oxford: Hart Publishing, 2014); E. Moavero Milanesi, "The importance of the state aids rules of the european union in the context of the global financial and economic crisis", Italian Antitrust Review, v. 1, issue 3 (2014): 1-6; Vittorio di Bucci, "The modernisation of state aid control and its objectives: clarity, relevance, effectiveness", Italian Antitrust Review, v. 1, issue 3 (2014): 7-23; Andrea Biondi, "The boundaries of EU state aid control rules", Italian Antitrust Review, v. 2, issue 1 (2015): 1-5.

${ }_{16}$ Paloma Ávila, "El papel de la Comisión Nacional de la Competencia en la actividad de la regulación de las administraciones públicas" in Derecho de la competencia y regulación en la actividad de las administraciones públicas, ed. Javier Guillén Caramés (Cizur Menor: Civitas Thomson Reuters, 2011), 375-392.

${ }^{17}$ José María Baño León, "La aplicación del derecho antitrust a la administración pública” in Derecho de la competencia ...., 61-86.

${ }^{18}$ Julio Costas Comesaña, "La sujeción de la actividad de la Administración al Derecho de la Competencia", Estudios de derecho mercantil: Libro homenaje al Prof. Dr. Dr.h.c. José Antonio Gómez Segade,
} 


\section{The role of the administration in applying regulations to defend competition}

One way in which the public administration can influence markets and distort free competition is through laxity in the application of rules in certain social situations. Economic crises seem to be a breeding ground for complaints of laxity in the application of competition rules. ${ }^{19}$

The reason for of this behaviour is that, although the protection of competition rights is seen as clearly positive in terms of the general good and of consumer protection, it is also viewed less favourably by firms and other operators, who see the resulting rules as constraints that prevent them from using the most effective ways of making the biggest, fastest profits. ${ }^{20}$

In times of serious economic crises, there is a tendency to call for greater protectionism and more constraints on competition in markets, allegedly to help sustain the economy until better times come around. ${ }^{21}$

Competition law clearly limits freedom of business and constrains the freedom to reach agreements, as the State seeks to protect the interests of the weakest links in the economic chain..$^{22}$ It must also be recognised that by establishing such protection, the State limits its own actions and its own freedom of action for the sake of the common good. ${ }^{23}$

When a crisis threatens the survival of numerous firms, it is no surprise that the argument is raised that maintaining constraints on the actions of businesses is conducive to their decline, with all the serious, negative consequences for society that may be associated with firms going out of business. ${ }^{24}$

In those circumstances, national and international authorities are asked to be more flexible in applying competition law, or indeed to cease to apply it altogether to certain sectors or over a certain timeframe. ${ }^{25}$ Answering to those questions in a positive way would be a mistake. ${ }^{26}$

This is a call for limits on the control of restrictive conduct on the part of businesses, so exemptions from prohibition are extended to certain 'restructuring agreements', with the application of an exemption for acquisitions in bankruptcy in

ed. Ana María Tobío Rivas et al. (Madrid: Marcial Pons, 2013), 369-381.

${ }^{19}$ Santiago Martínez Lage and Amadeo Petitbó Juan (ed), El derecho de la competencia en tiempos de crisis (Madrid: Marcial Pons, 2010).

${ }^{20}$ Aleix Calveiras and Juanjo Ganuza, "Ante la crisis ecónomica, apostar por la competencia" ["Supporting Competition in the Face of the Economic Crisis"] in Lo que podemos aprender de la crisis para España ¿Qué hacer para salir de esta crisis?, s/e, e-book (Sociedad Abierta, 2010).

${ }^{21}$ Rosa Otxoa-Errate Goikoetxea; Igone Altzelai Uliondo and Juan Manuel Velázquez Gardeta, Pyme y crisis económica: respuestas normativas de la UE (Cizur Menor: Aranzadi, 2010).

${ }^{22}$ Ana Balcells Cartagena, "European competition policy during the crisis: the approach of the European Comission", in Derecho de la Competencia europeo y español, ed. Luis Ortiz Blanco et al (Madrid: Dykinson, 2013), 391 - 444.

${ }^{23}$ Arianna Andreangeli, "EU competition law in times of crisis: between present challenges and a largely unwritten future", Competition Law Review, v. 9, issue 2 (2013): 91-118.

${ }^{24}$ European Commission, "Internal market: from crisis to opportunity - putting citizens and companies on the path to prosperity", The EU Explained (Brussels: EC, 2014).

${ }^{25}$ L. Berenguer Giménez, "El derecho de la competencia en un marco de crisis global" [Competition law in the framework of a global crisis"] in Revista de la Facultad de Ciencias Sociales y Jurídicas de Elche, v. 1, issue 6 (2010): 1-12.

${ }^{26}$ Juan Ignacio Signes de Mesa, Derecho de la competencia y crisis económica. El régimen de ayudas públicas y de concentraciones en el sector financiero (Pamplona: Aranzadi, 2013). 
company concentration, or with temporary relaxation of control procedures in the control of public-sector aid to allow aid in sectors or at thresholds where it would not generally be permitted. ${ }^{27}$

These arguments must be seen as a trap by firms for the market, the economy and the best interests of the weakest links in the chain. ${ }^{28}$

It is true that crises can have negative consequences for business, for the market and for consumers. ${ }^{29}$ However, it is a fallacy to argue that a more permissive approach towards abusive practices can help remedy matters. ${ }^{30}$

The essence of free competition is to reward the most efficient operators and expel the least efficient ones from the market: this is beneficial to the general interest. ${ }^{31}$ Also, it results in a renewal of production structures to adapt to changing market situations. ${ }^{32}$

That does not mean that national and supra-national authorities should ignore the short-term situations of businesses, but they must act with caution. ${ }^{33}$

When agreements can help to improve output or distribution, can foster technical and financial progress, can reserve a fair share in profits for users and can establish restraints that are essential for restructuring, certain measures may be permissible provided that a limited timeframe is maintained. ${ }^{34}$ Another option, which is perhaps less harmful to the general interest and more in accordance with the most effective competition policies, is merely to reduce the fines imposed if the crisis is found to be a true mitigating circumstance in any liabilities. ${ }^{35}$

In cases of business concentrations, for the crisis to be taken into account, there

${ }^{27}$ Miguel Moura e Silva, "Antitrust in distress: causes and consequences of the financial crisis" in Competition Law Review, v. 9, issue 2 (2013) 119-132.

${ }^{28}$ Gianni lo Schiavo, "The impact of the EU crisis-related framework on state aids to financial institutions: from past practice to future prospects" in Competition Law Review, v. 9, issue 2 (2013): 135-168.

${ }^{29}$ Luís Silva Morais, "Competition law and policy in times of crisis and economic change", in Competition Law Review, v. 9, issue 2, (2013): 81-90.

${ }^{30}$ Henk Don and Siún O'Keeffe, "Competition in times of crisis: we cannot afford to forget it', in Italian Antitrust Review, v. 2, issue 1 (2015): 25-34.

31 Julio Costas Comesaña, "Cárteles de crisis" in El derecho de la competencia en tiempos de crisis, ed. Santiago Martínez Lage (Madrid: Marcial Pons, 2010), 43-64.

${ }^{32}$ Juan Ignacio Signes De Mesa, Derecho de la competência...

${ }^{33}$ José Antonio Rodríguez Míguez, "Ayudas a la banca y crisis financiera en España”, in Estudios de derecho mercantil...

${ }^{34}$ On several occasions the European Commission has refused to relax competition rules when a crisis was alleged as a reason (the case of the zinc producer group on 6/08/1984, OJ L 220; the case of polypropylene on 23/04/1986, OJ L 230; the decision on bituminous coverings on 10/07/1986, OJ L 232; the cases of PVC and LdPE on 21/12/1988, OJ L 74 of 1989; the decision on electro-welded mesh on 2/08/1989, OJ L 260). However, on other occasions authorisation has been granted, with the precautions indicated above. Examples include the decision on synthetic fibres on 4/07/1984, OJ L 207 of 1984 and the Stichting Baksteen case (decision on 29/04/1994, IV/34.456). The same can be said of reciprocal specialisation agreements between firms with structural overcapacity, which are intended to bring about a co-ordinated reduction in economically unbearable overcapacity by closing down the most obsolete facilities and having each firms specialise in the sector in which it is likely to be most competitive once it is restructured, though this may in no case include agreements on prices, market shares or distribution. See also the cases of Bayer/BP Chemicals, Decision 5/05/1988, IV/32.075 and Enichem/ICI Enichem/ICI, Decision 22/121987, IV/31.846.

35 Rafael Allendesalazar and Roberto Vallina, "Aplicación de las normas de competencia a las restricciones verticales en épocas de crisis", in El derecho de la competencia...; Massimo Merola; Jacques Derenne; José Rivas (eds.), Competition Law in times of Economic Crisis. In Need of Adjustment? (Brussels: Bruylant, 2013). 
must be no causal link between the concentration process and the deterioration in effective competition. ${ }^{36}$ This means that for the concentration process to be allowed, the company affected by the crisis must be bound to leave the market in the near future unless it is acquired by another company, there must be no other possibility of purchase that is less harmful to competition than the concentration announced, and it must be confirmed that if the concentration process does not take place, the assets of the company in difficulty will inevitably be lost from the market. ${ }^{37}$

In the case of aid, resalistic, consistent, far-reaching restructuring plans are generally required that are aimed at restoring company viability in the long-term. Aid is also made conditional on the re-establishment of long-term viability, on there being no undue distortion of competition (so that the positive effects outweigh the negative ones), on the limiting of aid to such amounts and times as are necessary for the restructuring process to attain its goals, on the full application of the restructuring plan and on supervision and annual reports. ${ }^{38}$

The final response of the Commission can be found in the Communication from the Commission - Temporary Community Framework for State Aid Measures to Support Finance in the Current Financial and Economic Crisis. ${ }^{39}$

\section{The administration under the application of competition principles. Better regulation policies}

As mentioned above, one way in which public administrations can alter the rules of the free market is through State aid. Such aid is regulated at both, Community, and domestic levels, establishing the criteria under which States can lawfully protect businesses in certain sectors or certain circumstances to favour their entry into markets or help them to remain there. However, this is not the only way in which administrations can influence markets.

The regulatory functions of public administrations habitually affect the operation of markets. ${ }^{40}$ It is commonplace for sectoral regulations to include rules that establish certain modes of operation recognised by the regulator which favour certain sectors or groups ${ }^{41}$ Defending competition is a worthwhile task on the part of public administrations, but it needs to be weighed up against other principles

\footnotetext{
36 Antonio Martínez Sánchez and Jaime Rodríguez Ordóñez, "Procedimiento especial para la aprobación de concentraciones en tiempos de crisis", in El derecho de la competencia...

${ }^{37}$ In this regard, see the decision Kali und Salz of 14/12/1993 (case M.308), OJ L 186 of 21/07/1994, p. 38 ss., section 71; the Court of Justice judgement Kali und Salv, case C-68/94, of 31/03/1998, section 110; the Basf decision on 11/07/2001 (COMP/M.2314), OJ L 132 of 17/05/2002, sections 157-160. Jorge Manzarbeitia and Pedro Callol, "Intervención pública en momentos de crisis: el derecho de ayudas de Estado aplicado a la intervención pública directa en las empresas", Serie Política de la Competencia, issue 29 (2009).

${ }^{38}$ Cani Fernández, "La supervivencia de las compañías en crisis (Failing Firm Defense)", in El derecho de la competencia...; Marcos Araujo, "Los remedios aplicados a concentraciones en tiempos de crisis", in El derecho de la competencia...; Juan Delgado and Eva Ferraz, "Política de competencia, política industrial y campeones nacionales en tiempos de crisis", in El derecho de la competencia...

${ }^{39}$ (OJ C 16/1 de 2009). Initially extended up to 31/12/2011 but in fact still in force, in view of the current economic situation.

${ }^{40}$ Carlos Gómez Asensio, La mejora regulatoria (Better Regulation) Aplicaciones en materia de contratación pública (Valencia: Tirant Lo Blanch, 2013).

${ }^{41}$ Adrien de Hauteclocque, Market building through antitrust, long-term contract regulation in EU electricity markets (Cheltenham: Edward Elgar, 2013).
} 
that favour the common good..$^{42}$ This argument leads numerous administrations to approve rules that favour certain operators, often to detriment of the best interests of the market and of consumers.

Certain heavyweight business organisations, lobbies and professional associations can influence political decision-making bodies sufficiently and lead administrations to adopt measures that do not truly coincide with the common good more often than would be desirable. ${ }^{43}$

Controlling public administrations in such cases is a complex matter.

Competition rules can only be applied by administrative authorities to companies or operators working in a given market. This requirement is not met in the case of administrations acting as regulators. ${ }^{44}$ Thus, to the extent that a public administration creates a set of regulations and exercises powers as an imperium, it places itself beyond the sanctioning reach of the competition authorities and raises a shield of impunity over those businesses that benefit from the rules applied, generally to the detriment of consumers.

\section{A. Supranational rules as reference to liberalisation}

There are two ways in which our legislation can take action against this clearly undesirable situation. ${ }^{45}$ One way of protecting markets against abusive actions by the administration is through supra-national regulations (particularly EU regulations in our case) that protect the values closest to the general interest and thus, favour the common good. ${ }^{46}$

A clear example of this situation can be found in the European Union in the form of the so-called Services Directive. ${ }^{47}$ This Directive has led to a real shake-up in the organisation of professional services for benefit of consumers. ${ }^{48}$ The approval of the Directive in 2006 and its transposition into Spanish law in 2009 sought to create a framework for regulating professional services that would be consistent with the defence of free competition in the markets affected. ${ }^{49}$ The reforms introduced by the Directive call for proper application by the institutions involved in preparing and implementing them, to avoid tension between the principles contained in the

\footnotetext{
${ }^{42}$ Björn Lundqvist, Standarization under EU competition rules and US antitrust laws: the rise and limits of self-regulation (Cheltenham: Edward Elgar, 2014).

${ }^{43}$ Kevin Coates, Competition law and regulation of the tecnology markets (Oxford: Oxford University Press, 2011).

${ }^{44}$ Niamh Dunne, Competition law and economic regulation: making and managing markets (Cambridge: Cambridge University Press, 2015).

${ }^{45}$ Josef Drexl and Fabiana di Porto (eds.), Competition law as regulation (Cheltenham: Edward Elgar, 2015).

${ }^{46}$ Giorgio Monti, "Managing the intersection of utilities regulation and EC competition law", in Competition Law Review, v. 4, issue 2, (2008): 123-145.

${ }^{47}$ Markus Krajewski, National regulation and trade liberalization in services - the legal impact of General Agreement on Trade in Services (GATS) on national regulatory autonomy (The Hague: Kluwer Law International, 2003).

${ }^{48}$ Isabel Sánchez, "La transposición de la Directiva de servicios en España", in El derecho de la competencia...; Josu J. Sagasti Aurrekoetchea, "La normativa de liberalización de servicios y la actividad de notario y de profesiones jurídicas" in Revista Crítica de Derecho Inmobiliario 730 (2012): 745-797

${ }^{49}$ Directive 2006/123/EC of the European Parliament and of the Council of 12 December 2006 on services in the internal market, OJ L 376 of 27.12.2006, pp. 36-68; Act 25/2009 of 22 December on the amendment of various laws to bring them into line with the Act on Free Access to Service Activities and Their Exercising (the Omnibus Act) and Act 17/2009 of 23 November on Free Access to Service Activities and Their Exercising (the Umbrella Act).
} 
Regulations and the way in which they are applied. ${ }^{50}$

These Regulations have given rise, for instance, to in-depth discussions on the role to be played by professional associations as a barrier to entry in certain markets, or as a form of corporatist protection of members against market competition. ${ }^{51}$ That discussion led the administration to consider introducing changes to the rules, given that under EU Regulations, professional associations with compulsory membership are only permitted if such associations already exist. ${ }^{52}$

Inside the European countries, and with regard to the existence and operation of certain professional associations, it is clear that "there continue to be numerous barriers to access to professional activities and to the practising of a profession that prevent or hinder freedom of provision of professional services". ${ }^{53} \mathrm{It}$ is also significant that there is "a lack of specific adaptation of the Regulations in place in the autonomous regions governing professional associations, to the reforms envisaged in basic nationwide legislation, thus fostering the geographical compartmentalising of the domestic market and reducing the potential for competition in the various territories". ${ }^{54}$ This is why it would be advisable that the government specify what activities and professions should be subject to an exceptional framework of compulsory membership of associations, bearing in mind that compulsory membership is a major constraint on competition, "so that in all those cases in which it is deemed necessary, reasonable justification must be given of the need, the proportionality and the absence of discrimination of the relevant measure" ${ }^{55}$

Spain's Constitutional Court had already indicated that it was up to lawmakers to determine what professions were excluded from the general principle of freedom, in order to assess which of them required compulsory membership of a professional association and, as the case may be, to determine the degree of importance that should be attributed to qualifications as a prerequisite for practising a profession. ${ }^{56}$

The Spanish Constitutional Court also indicates that for a profession to be classed as requiring compulsory membership of a professional association, it is necessary from a constitutional point of view, to imply a general interest that could be affected.$^{57}$ In other words there must be constitutionally significant public purposes in the activity made by those professionals. ${ }^{58}$ The legitimacy of such decisions

\footnotetext{
${ }^{50}$ Comisión Nacional de la Competencia. Informe sobre los colegios profesionales tras la transposición de la Directiva de Servicios. Madrid, 26 de abril de 2012, en CNC, http://www.cncompetencia.es/Inicio/ Noticias/tabid/105/Default.aspx?Contentid $=475051$.

${ }^{51}$ Christian Bergqvist, Between regulation and deregulation (Copenhage: Djof Publishing, 2017).

${ }^{52}$ Germà Bel, Joan Calzada and Xavier Fageda, "Liberalización en los servicios públicos de red" in Anuario de la competencia (2006): 177-208.

${ }^{53}$ Report by Spain's Competition Authority dated May 2012, "Los Colegios Profesionales tras la transposición de la Directiva de Servicios" ["Professional Associations Following the Transposition of the Services Directive"].

${ }^{54}$ M.P. Espinoza, A. Ciarreta and A. Zurimendi, Reforma del mercado de servicios profesionales (Madrid: Funcas, 2014).

${ }^{55}$ Juan Espinosa García, "Servicios públicos locales y competencia” en Derecho de la competencia y regulación... ; Comisión Nacional de ka Competencia, Informe sobre el sector de servicios profesionales y los colegios profesionales, Madrid, Septiembre de 2008.

${ }^{56}$ Constitutional Court judgements 194/1998 and TC 76/2003 of 23 April, FJ 4.

${ }^{57}$ Luis Berenguer Fuster, "La necesaria modernización de los colegios profesionales en España" in Anuario de la Competencia (2010): 13-36; Comisión Nacional de Competencia, I26/0007/08 Recomendaciones a las Administraciones Públicas para una regulación de los mercados más eficiente y favorecedora de la competencia, Madrid, 18 de junio de 2008.

${ }^{58}$ Germán Fernández Farreres et al, Colegios Profesionales y Derecho de la Competencia (Madrid: Civitas, 2002).
} 
depends on whether professional associations effectively play a role in safeguarding the interests of the recipients of the services provided by their members ${ }^{59}$ and also, on the relationship that exists between each specific professional activity and specific rights, values and goods that are protected under the constitution. ${ }^{60}$

There is, therefore, an obligation incumbent upon public administrations (the central Spanish administration as regards basic issues and also the administrations of the autonomous regions) to amend their Regulations to bring professions into line with supra-national Directives and, thus, protect competition and consumers. ${ }^{61}$ Otherwise, the interest of the lobbies would be protected over the interest of the clients. $^{62}$

\section{B. The capacity to challenge rules before the courts}

The second way of controlling the regulatory role of the administration is to challenge, in court, the regulations that have recently been approved by the administration if they are deemed contrary to the competition principles.

Spanish Competition Law permits central and regional competition authorities to file objections before competent courts for maintaining effective competition in markets [Articles 12(3) and 13(2) Competition Act]. ${ }^{63}$ The aim is to challenge acts of public administrations and general provisions of the administration, if their rank is below the law and if those acts give rise to obstacles to free competition in the market. ${ }^{64}$

The Competition Act openly envisages the possibility of competition authorities going to the courts and appealling national, regional or local regulations that are deemed to be in breach of the principles of competition and, therefore, detrimental to the interests of consumers and contrary to the public good, or biased in favour of certain operators or groups of operators. ${ }^{65}$

This legal instrument is regarded as a last resort that is to be used restrictively, due to the dysfunctions that Regulations in force can generate in markets. ${ }^{66}$

\footnotetext{
${ }^{59}$ Francisco Javier de Ahumada Ramos, "Colegios profesionales: régimen aplicable y propuestas para un cambio de modelo", in Las técnicas de regulación para la Competencia: una visión horizontal de los sectores regulados, ed. Juan Alfonso Santamaría Pastor et al (Madrid: Iustel, 2011), 573-613.

${ }^{60}$ Supreme Court judgement of 26 April 2010.

${ }^{61}$ Consejo General del Poder Judicial. Los colegios profesionales. Administración corporativa (Madrid, 2001).

${ }^{62}$ G. Aranzabe Pablos, "Colegios Profesionales y Defensa de la Competencia: la experiencia vasca", in Gaceta Jurídica de la Unión Europea y de la Competencia, La Ley, issue 12, (2009): 43-54.

${ }^{63}$ Alfredo González-Panizo Tamargo, "Legitimación activa de la CNC para el ejercicio de acciones jurisdiccionales: objeto, motivos de impugnación y pretensiones ejercitables" in Anuario de la Competencia (2010): 115-132.

${ }^{64}$ Javier Guillén Caramés, "La impugnación por las autoridades de competencia de las actuaciones de las administraciones públicas restrictivas del derecho de la competencia" in Derecho de la competencia y regulación...

${ }^{65}$ This possibility has been invoqued by the National Competition Authority, which has appealed against decrees in the field of transport issued by the regional governments of Valencia and Galicia, and against one set of national regulations. The National Competition Authorithy has used the option 8 times. Also the Basque Competition Authority has used the option 7 times for transport contracts and local regulations about restaurants and bars.

${ }^{66}$ Javier Guillén Caramés, "La promoción de la competencia como refuerzo al ejercicio de potestad sancionadora por parte de las autoridades de competencia: en especial, la impugnación de la actividad administrativa contraria al Derecho de la Competencia" in Cuestiones actuales del procedimiento sancionador en Derecho de la Competencia, ed. Javier Guillén Caramés (Cizur Menor: Civitas, 2013), 369-399.
} 
The advocacy power is considered to be of crucial importance in this regard. ${ }^{67}$ Thus, there are general and specific reports addressed to public administrations that offer them instruments for improving their regulatory work. ${ }^{68}$

The possibility of drawing up reports during the lifetime of regulatory processes that can be used preventively to forestall problems of competition arising from regulations as they are drawn up could be another equally effective and less intrusive system. ${ }^{69}$ This solution entails that such reports are actually taken into account by the administrations charged with setting up regulations. ${ }^{70}$

The Spanish Competition Act assumes that those powers of competition authorities just work when there is no Regulation with the rank of law that limits competition principles. ${ }^{71}$ Those riules give rise to legitimate expectations on the part of operators and it is established that competition prevails over the exercise of other values that are considered more relevant by Parliament (see Article 4(2) of Competition Act 15/2007). ${ }^{72}$

\section{Administration as possible actor in a cartel}

Lots of different views have been offered about the possibility of competition authorities to consider the administration as passive part in an antitrust behaviour and therefore to consider it part of an infringement. ${ }^{73}$

The Supreme Court judgement dated 26 April 2010 establishes that [...] "In the face of this partial exclusion from the subjection of the actions of public administrations to competition law when they act in their role as public administrations, it is necessary to assert that they are fully subject to the said regulations, (...). Indeed, the fact that economic actors are mentioned in the said provision should not be understood as meaning that only those actors subject to private law and not those subject to administrative law are liable to sanctions under the said legislation,

\footnotetext{
${ }^{67}$ Alfredo González-Panizo Tamargo, "Legitimación activa de la CNC para el ejercicio de acciones jurisdiccionales: consideraciones generales, motivos de impugnación y supuestos de intervención judicial" in Cuestiones actuales...; Jorge Masía; José María Jiménez-Laiglesia Oñate, "Promoción de la competencia" in Derecho de la competencia y regulación..

${ }^{68}$ See, for example, the recommendations for public administrations conducive to more efficient market regulation that favours competition in the document Trabajando por la Competencia ["Working for Competition"] by the CNC, prepared in line with OECD and EU directives.

${ }^{69}$ Arseni Gilbert, "Regulación y competencia" in Administración y Competencia - Un análisis de la labor general de la Administración y una especial mirada a la situación de competencia en los puertos, ed. Maria Pilar Canedo Arrillaga (Cizur Menor: Aranzadi-Thomson Reuters, 2015): 91-100.

${ }^{70}$ It is not unusual to find reports from competition authorities that bring to light dysfunctions caused to competition by certain regulations which are systematically ignored by public authorities, with the harm thus done to consumers and users of services being valued less highly than the corporate interests protected. In this regard see, for example, the situation as regards the regulation of public passenger transport (taxis) in several of Spain's autonomous regions (Report $\mathrm{n}^{\circ}$. 14/11 of the Andalusian competition authority on the draft bill for the regulation of public passenger transport services in saloon cars).

${ }^{71}$ Luis Antonio Velasco San Pedro, "La regulación económica como barrera a la competencia: liberalización y política de mejora de su calidad" in Derecho de la competencia y regulación...

${ }^{72}$ Ley 15/2007, de 3 de julio, de Defensa de la Competencia, BOE no 159, de 4 de julio de 2007; modificada por Ley 39/2010, de 22 de diciembre, BOE-A-2010-19703; Ley 2/2011, de 4 de marzo, BOE-A-2011-4117, y Ley 3/2013, de 4 de junio, BOE-A-2013-5940. Texto consolidado https:// www.boe.es/buscar/act.php?id=BOE-A-2007-12946. Juan Espinosa García, "Servicios públicos locales y competencia" in Derecho de la competencia y regulación...

${ }^{73}$ Edurne Navarro Varona and Marcos Rambal, "La aplicación de las normas de defensa de la competencia a las Administraciones Públicas que no actúan como operadores económicos en el mercado" en Gaceta Jurídica de la Unión Europea y de la competencia, no 31 (2013): 23-34.
} 
but rather as a reference to any actor that acts in the market, even when public administrations or publicly owned bodies and companies act subject to a greater or lesser extent to administrative law. ${ }^{74}$ Accordingly, although the aforesaid Additional Provision 6 to the Public Administration Procurement Act (RCL 1995, 1485, 1948) states that the company appearing as co-defendant is subject to the principles of disclosure and competition and that its acts must be seen as subject in part to administrative law, that does not mean that its external activities cannot be judged in any case from the viewpoint of the regulations on the defence of competition."

It is, therefore, clear that public administrations are, insofar as they act as economic operators, subject to the competition regulations and must comply with same in the drawing up of contracts, agreements and tenders. ${ }^{75}$ The idea of "economic activity" is defined broadly in such a way that those activities directly linked to the exercising of State prerogatives are usually excluded from the scope of action of the competition authorities. ${ }^{76}$

In this situation, companies involved in an agreement tend to alledge in court that, their actions are based on the principle of legitimate expectations, in that a situation has arisen in which an action by the administration has led them to believe that the agreement was lawful. ${ }^{77}$

The Spanish Competition Comission strongly refuted this argument. Firms in the well-known case of the sherry wine producers were accused of price-fixing, i.e. practices intended to restrict competition banned under Article 1 of the Act on the Defence of Competition (LDC) and Article 101 of the Treaty on the Functioning of the European Union (TFEU). ${ }^{78}$ The case has been confirmed by the Supreme Court of Spain. ${ }^{79}$

The organisations representing producers and processors in the Sherry Triangle alleged legitimate expectations as a mitigating circumstance, given that the Spanish Ministry of Agriculture and Andalusian Regional Ministry of Agriculture were aware of the facts.

The principle of legitimate expectations, as set out in Article 3.1.1 of the Act for the Reform of the Legal Framework of Public Administrations, does indeed establish that public administrations must comply with the principles of good faith and legitimate expectations. ${ }^{80}$ However the said principal must be interpreted restrictively and within the scope of the law, which means that legitimate expectations can only be generated by those authorities which are competent to authorise the acts in question. ${ }^{81}$

Indeed, the principle of legality must be understood to prevail over any manifestly

\footnotetext{
${ }^{74}$ Carlos Padrós Reig, "La presencia de la Administración Pública en cárteles privados: la regulación administrativo-colusoria" in Revista General de Derecho Administrativo, no 32 (2013): 1-26.

${ }^{75}$ See the Guide to Public Procurement and Competition published by the CNC, based on those of the OECD and the EU.

${ }^{76}$ Accordingly, see the judgements of the European court for illustrative examples of these two facets of the actions of public administrations. CJEC 17 February 1993, C-159/91 \& C- 160/91, Poucer, Assurances Generales de France, and CJEC 19 February 1994, C-364/92, Fluggesellschaft Eurocontrol.

77 Julio Costas Comesaña; Joaquim Hortalà Vallve, "La tipificación de la actividad de la Administración como facilitadora de cárteles" in Anuario de la Competencia (2014), 13-32.

${ }^{78}$ Case-file S/0167/09 Sherry Grape and Wine Producers, rejecting the argument of legitimate expectations.

${ }^{79}$ Judgement of the Spanish Supreme Court of 20th July 2016.

${ }^{80}$ Julio Costas Comesaña, "La confianza legítima en la actuación de las administraciones públicas como límite al derecho de defensa de la competencia" in Derecho de la competencia y regulación...

${ }^{81}$ Supreme Court judgement dated 14 February 2006.
} 
unlawful behaviour, even if the conduct of the administration is incorrect. ${ }^{82}$

In the case taken as an example here, the $\mathrm{CNC}$ considers that the Ministry of Agriculture of the Regional Government of Andalucia holds authority in the matter, but does not have the authority to determine whether the practices analysed comply or not with the rules on the defence of competition: only the competition authorities have that power..$^{83}$

The silence, or even acquiescence, of an authority not competent to apply competition rules cannot be deemed to generate legitimate expectations. No signatory to an agreement could expect such actions to be lawful, given that pricefixing agreements are prohibited and the sanctions applicable by the competition authorities to such behaviour are known.

Action taken by the administration to bring the positions of operators in a sector closer together, leading firms to enter into a restrictive agreement (not imposed or caused by the administration) cannot be deemed to generate expectations, excluding culpability.

The administration is, thus, considered as participating in the infringement and subject to competition law. ${ }^{84}$

\section{The role of the administration in public procurement procedures}

The administration is also one of the most relevant actors in the national markets through public procurement. ${ }^{85}$ In European countries, the percentage of GDP that public procurement implies is between 20 and $30 .{ }^{86}$

Beginning around 20 years ago, there is a general worry in international organizations for the non application of competition rules in public procurement procedures and the problems this situation implies in all the economies of the world. ${ }^{87}$ There is a clear relation between competition and corruption and the application of

\footnotetext{
${ }^{82}$ Supreme Court judgement dated 20 December 2006.

${ }^{83}$ See the judgement of the Court for the Defence of Competition (TDC) dated 3 June 1997 (Dairy Industries), the judgements of the CNC Council dated 4 June 2009 (Regulatory Council for the Sherry Wine Designation of Origin), 28 July 2010 (Sherry Wines), 26 April 2008 (the Mussel Industry Platform) and 13 May 2011 (UNESA); and the Decisions of the European Commission dated 2 April 2003 (French Beef Producers) and 20 October 2004 (Spanish Raw Tobacco). In the case of Spanish Raw Tobacco, the Committee considered that the alleged mitigating circumstances of coverage by the law and "incitement" by the public administration did not constitute exoneration from the obligation to apply competition rules. In the French Beef Producers Decision, the Commission establishes that the Ministry of Agriculture participated to a large extent in price fixing agreements between organisations representing beef producers and slaughterhouses in France on the occasion of the mad cow disease crisis, and this was actually published in the media. However, the active participation of the Ministry was not sufficient for it to elude competition law even though Ministry participation was taken into account as a mitigating factor.

${ }^{84}$ José Carlos Laguna de Paz, Derecho de la competencia y regulación en la actividad de las administraciones públicas (Cizur Menor: Civitas, 2011): 153-177.

${ }^{85} \mathrm{OCDE}$, Lineamientos de la OCDE para combatir la colusión entre oferentes en contrataciones públicas, Paris, 2009. DAF/COMP(2009)1/FINAL]. http://www.oecd.org/daf/competition/Recommendation_ fighting-bid-rigging-2012-ES.

${ }^{86}$ Antonio Lopez Miño et al, "Buenas y malas prácticas en contratación de la competencia" in Administración y Competencia...

${ }^{87}$ Organisation for Economic Cooperation and Development. Recommendation of the OECD Council on Fighting Bid Rigging in Public Procurement. 17 July 2012. http://www.oecd.org/daf/ competition/RecommendationOnFightingBidRigging2012.pdf. Mercedes Pedraz, "Los contratos públicos y la defensa de la competencia" in Derecho de la competencia y regulación ....
} 
competition rules can be a way of triyng to stop this tendency. ${ }^{88}$

The recent EU Directives on Public Procurement have shown a huge step in the application of competiton principles to public procurement and the show the interest of the organisation in protecting fairness in the market through transparency, equality of opportunities and protection of weaker parties. ${ }^{89}$

The application of competition rules to public procurement implies in a relevant number of cases, bid rigging practices. ${ }^{90}$ This implies that companies alter the rules of a public tender in order to change the selection that would be more efficient for the administration and obtaining a result that would be better for their interest and therefore, negative for the public interest. ${ }^{91}$

The harm created by these agreements is comparable to the one created by the cartels, but the fact that they modify public procurement procedures and therefore, imply public money, make them much more harmful to society. ${ }^{92}$

These kinds of agreements are also much more difficult to detect because the administration is not as flexible as particulars in the process of contracting and also, because there is a clear asymmetry of information and the administration does not control the information of the market as easily as the private companies. ${ }^{93}$ A clear case of this asymmetry is shown in cases of parcelation of the market through agreements of sharing of contracts of different administrations.

There is, nevertheless, another less studied problem of competition related to public procurement and this is created by the administration through the conscious or inconciour incorrect design of the call for proposals in a tender procedure. ${ }^{94}$

The role of the competition authority in these cases is also very relevant because they should have to be able to convince the administration about the benefits that competition brings to public procurement procedures before they are open to the public..$^{95}$ This can be done through cooperation between the contracting

\footnotetext{
${ }^{88}$ Miguel Cuerdo Mir, "Subastas y contratación administrativa desde la perspectiva económica del derecho de la competencia" in Derecho de la competencia y regulación...

${ }^{89}$ M. Browsher, UK Procurement Law: principles and practice. (Oxford: Hart Publishing, 2014); Albert Sánchez Graells, "Public Procurement ; An Overviiew of EU and National Case Law (from an EU Competition Law Perspective)" in E-Competitions, National Competitions Laws Bulletins, issue 40647 (2011); Albert Sánchez Graells, "Competition Neutrality in Public Procurement and Competition Policy: An Ongoing Challenge Analised in View of the Proposed New Directive" in, Conference Papers, ed. International Public Procurement Conference (IPPC), 2012; Robert D. Anderson; William E. Kovacic, "Competition Policy and International Trade Liberalisation: Essential Complements to Ensure Good Performance in Public Procurement Markets", in Public Procurement Law Review, vol. 18 (2009): 67-101; Maria Pilar Canedo Arrilaga, "An attempt to increasing competition in public procurement: one example in the Basque Country", in Fostering Growth in Europe: Reinforcing the Internal Market, ed. J.M. Beneyto et al (Madrid: CEU, 2014), 365-389; Petros C. Mavroidis et al, The internationalization of government procurement regulation (Oxford: Oxford University Press, 2017).

${ }^{90}$ Francisco Hernandez Rodriguez, "Contratación y Competencia" in Administración y Competencia...

${ }^{91}$ Guillermo Aranzabe Pablos, "Contratación administrativa y administración local en la Autoridad Vasca de la Competencia. El caso Pinosolo", in Estudios de Deusto; v. 63/1 (2015): 131-148.

${ }^{92}$ Fernando Jiménez Latorre and Javier Coronado Saleh, "Análisis económico de la colusión en mercados de subastas: pujas fraudulentas (Bid rigging)", in Los acuerdos horizontales entre empresas, ed. Santiago Martinez Lage et al (Madrid: Marcial Pons, 2009), 213-242

${ }^{93}$ Maria Pilar Canedo Arrillaga, "Algunas consideraciones jurídicas en torno a prácticas de 'Bid Rigging", in Gaceta Jurídica de la Unión Europea y de la Competencia, issue 36 (2013): 9-19.

${ }^{94}$ R.C. Marshall and L.M. Marx, The economics of Collusion. Cartels and Bid rigging (Massachussets: The MIT Press, 2012).

${ }^{95}$ Javier Guillén Caramés, "La promoción de la competencia como refuerzo al ejercicio de potestad sancionadora por parte de las autoridades de competencia: en especial, la impugnación de la
} 
administration and the competition authority. ${ }^{96}$

The other option open to the competition authority is the possibility of challenging the rules of the tender before the courts, in order for them to decide if there is breach of the competition principles in the prodecure. ${ }^{97}$

\section{Conclusions}

The role of public administrations in markets as regulators, providers of aid, economic operators or facilitators of contracting between companies is highly significant and may have a major influence on those markets. The proper exercise of these functions results in highly positive values for consumers and in an increase of the common good. Improper actions of the administration can be seriously harmful to the general interest.

In situations of crisis, relaxing competition regulations may seem to be a reasonable, simple solution. However, such action will only exacerbate the crises, increase the harm done to consumers and cause long-term damage which the market will have great difficulty in reversing. ${ }^{98}$

Ensuring the proper operation of the markets is essential if periods of economic recession are to be overcome. Economies do not emerge from recessions unaided. Economic recovery requires entrepreneurs and innovation, so it is essential for the doors to the market to remain open. On the one hand, this prevents governments from falling into the temptation of promoting greater protectionism with the creation of national champions. On the other hand, it ensures that the foundations of the market economy are maintained during crisis periods, and no barriers to economic activity are raised that could result in irreversible damage and perpetuate the crisis.

Public administrations must fulfil their mandate of guaranteeing the general good, shying away from sectoral interests that could bring increased short-term benefits but result in dysfunctions and harm for the common good and for consumers.

\footnotetext{
actividad administrativa contraria al Derecho de la Competencia" en Cuestiones actuales...

${ }^{96}$ Examples of this cooperation can be found in reports as those cited. CNMC, INF/DP/0007/14 Informe sobre los pliegos del procedimiento abierto de contratación de servicios consolidados de telecomunicaciones de la Administración General del Estado. Madrid, 13 de junio de 2014, en CNMC, http://www.cnmc.es/Portals/0/Ficheros/Promocion/Informes_sobre_normativa/2014/201408_ INF_DP_0007_14.pdf; CNMC. INF/DP/0009/14 Informe sobre pliegos del contrato centralizado de servicios de seguridad integral y de auxiliares de control en edificios de la Administración General del Estado y sus organismos. Madrid, 14 de mayo de 2014, en CNMC, http://www.cnmc.es/ Portals/0/Ficheros/Promocion/Informes_sobre_normativa/2014/201408_INF_DP_0009_14_ INFOR.pdf; CNMC, INF/DP/0012/14 Informe sobre los pliegos del contrato de servicios postales de la Administración General del Estado (fase I). Madrid, 25 de junio de 2014, en CNMC, http://www.cnmc.es/Portals/0/Ficheros/Promocion/Informes_sobre_normativa/2014/201408_ INF_0012_14_AGE_postales.pdf; CNMC, INF/CNMC/004/15 Informe sobre los pliegos que rigen la celebración del acuerdo marco para la contratación de servicios de desarrollo de sistemas de administración electrónica; 29 de septiembre de 2015; 19 págs; www.cnmc.es.

${ }^{97}$ Alfredo González-Panizo Tamargo, "Legitimación activa de la CNC para el ejercicio de acciones jurisdiccionales: consideraciones generales, motivos de impugnación y supuestos de intervención judicial" in Cuestiones actuales...

${ }^{98}$ In the words of the former Competition Commissioner, Neelie Kroes, "no-one wins - today's softness is tomorrow's nightmare".
} 